\title{
Lipid markers and compound-specific carbon isotopes as diet and biosynthesis reflectors in the northern Neptune whelk Neptunea heros
}

\author{
H. Rodger Harvey*, Rachel McMahon, Karen A. Taylor \\ Department of Ocean and Earth Sciences, Old Dominion University, Norfolk, Virginia 23529, USA
}

\begin{abstract}
A suite of lipid biomarkers plus compound-specific carbon isotopes of major sterols were determined in muscle tissues across increasing sizes of northern Neptune whelks Neptunea heros, developing eggs and potential diets to link trophic patterns, metabolism and carbon sources on the Chukchi Sea shelf. Analysis of primary prey included the northern clam Astarte borealis, water column particulate organic matter (POM) and surface sediments near the collection sites. Sterols specific to major algal groups along with algal-derived polyunsaturated fatty acids (C20:5n-3, C20:4n-3, C22:6n-3) in whelk muscle tissue reflected the importance of algal primary production to benthic consumers and its direct incorporation. Compound-specific carbon isotope values of cholesterol and $\Delta^{5,7}$-sterols present in foot muscle of $N$. heros also suggest a transition from scavenging/detrital feeding in smaller juveniles to predatory consumption by larger adults. Sexually mature adult female $N$. heros (shell lengths $>10 \mathrm{~cm}$ ) contained lower sterol concentrations compared to smaller whelks, which may reflect reduced consumption rates or lipid translocation during the annual reproductive cycle. Analysis of $N$. heros eggs at 3 developmental stages ranging from internal egg masses to mature egg cases showed significant transfer of algalderived sterols and fatty acids which were conserved during egg maturation. The suite of individual lipid signatures and $\delta^{13} \mathrm{C}$ sterol values observed in $N$. heros suggest that the northern Neptune whelk relies on both direct lipid incorporation as well as metabolic modification of algal-derived food sources for sterol requirements that transition as animals mature and become predatory consumers.
\end{abstract}

KEY WORDS: Neptunea heros · Astarte borealis · Arctic Ocean · Lipids · Sterols · Trophic relationships $\cdot$ Carbon cycling $\cdot$ CSIA

\section{INTRODUCTION}

The Arctic Chukchi Sea represents a transition region between the North Pacific and the Arctic, where the advection of warm, nutrient-rich water as well as primary and secondary producers transported from the Bering Sea are mixed over its shallow shelf (Grebmeier et al. 2018). The poleward movement of Pacific water from the Bering Strait and its impact on circulation (e.g. Weingartner et al.

\footnotetext{
*Corresponding author: rharvey@odu.edu
}

2005) and nutrient distributions (see Lin et al. 2019) to the Chukchi Sea are well documented. Northward flow across the shallow $(50 \mathrm{~m})$ Chukchi shelf follows several paths northward, with primary production strongly influenced by local winds and historic ice cover over 7-8 months of the year. As a result, primary production in the water column and from ice algal production is strongly seasonal and substantial; total primary production at ice melt is estimated at $>400 \mathrm{~g} \mathrm{C} \mathrm{m}^{-2} \mathrm{yr}^{-1}$ despite seasonal ice cover (Greb-

() The authors 2021. Open Access under Creative Commons by Attribution Licence. Use, distribution and reproduction are unrestricted. Authors and original publication must be credited. 
meier et al. 2018). The rapid and efficient transfer of primary production to the benthos is a common feature here and among other high latitude marine systems and has also been reported in the southeastern and northern Bering Sea (McConnaughey \& McRoy 1979, Highsmith \& Coyle 1990) and northwest Barents Sea Marginal Ice Zone (Tamelander et al. 2006). The freshly produced primary production reaching the seabed supports high biodiversity and species richness of benthic communities in the Chukchi Sea continental shelf and a tight coupling between pelagic and benthic realms (Grebmeier et al. 1989, Iken et al. 2010). The rapid sedimentation to the benthos provides a supply of labile organic matter influencing benthic biomass, trophic structure and organic carbon (OC) cycling on the shelf (Feder et al. 2005, 2011).

Epibenthic organisms are particularly important contributors to the overall energy turnover on Arctic shelves such as the Chukchi through active bioturbation and trophic interactions with infauna, demersal fishes and marine mammals (Feder et al. 1994, Bluhm et al. 2009). On the Chukchi shelf, quantitative assessments of the epibenthos have shown the ubiquity of the northern Neptune whelk Neptunea heros (family Buccinidae) (e.g. Ravelo et al. 2014). Although assumed to be mainly scavengers as juveniles, as adults $N$. heros are also high trophic level predators, with bivalves and polychaetes as their main prey items (MacIntosh \& Somerton 1981, North et al. 2014). Although lacking the accessory boring organ found in other carnivorous gastropods, N. heros utilize their extremely long proboscides and muscular foot to prey on large clams and benthic infauna (Shimek 1984). In the related gastropod N. arthritica (Fujinaga \& Nakao 1999) and others that include Hemifusus tuba, food consumption rates and shell length generally show an inverse relationship, as juveniles allocate a significant amount of energy to increase shell size and reduce predation pressure compared to mature individuals (Morton 1990). For some species, food consumption rates also appear to correspond with reproductive cycles. For example, $N$. arthritica displays a non-feeding winter phase followed by minimal feeding during copulation/spawning in spring; its maximum growth and feeding subsequently occurs during summer and fall with gonad maturation (Fujinaga \& Nakao 1996). For most species, eggs with developing gametes are initially held internally and then cast on shells of conspecifics during gestation and development.

Despite the potential for a wide range of foods, bivalve fragments (ctenidial remains, shell fragments or siphonal coverings) are frequently observed as the main gut contents in adult $N$. heros and related $N$. antiqua and N. ventricosa (Taylor 1978, Shimek 1984). A common bivalve prey of $N$. heros throughout the Arctic is the northern clam Astarte borealis (North et al. 2014). As a slow-growing species, A. borealis reach only $3-4 \mathrm{~cm}$ in size as adults, yet it is a cosmopolitan benthic suspension feeder with a varied diet (Saleuddin 1965) and broad distribution (MüllerLupp \& Bauch 2005). A. borealis also appears to contain significant lipids in its adductor muscle, which makes it an attractive prey to predators during fall and winter when ice cover and reduced sunlight limit new production and the availability of lipid-rich and nutritionally valuable algal detritus.

This study examined diet and metabolism reflected in the abundance and distribution of lipid markers in $N$. heros and several potential diets. In this role, lipids represent not only essential metabolic requirements, but can provide molecular proxies for tracing diet history and processing (e.g. Viso \& Marty 1993, Morais et al. 2003). Sterols were a major focus here as they have been shown to provide taxonomic resolution for a number of eukaryotes which have distinctive composition, especially in differentiating algal and animal origins (e.g. Volkman 1986). The taxonomic source specificity that individual sterol structures can provide was expanded through the analysis of compound-specific carbon isotopic analysis (CSIA) of major sterols in $N$. heros to investigate if isotopic values allow insight into the balance of direct incorporation versus metabolic synthesis or modification of these structural lipids (e.g. Gergs et al. 2015). Sterols and other lipids have shown their value for seasonal examination of diet trends in other mollusks such as scallops (Lavaud et al. 2018), but here, foot muscle tissues of whelks from juveniles to gravid adults were characterized to determine if lipid composition reflected long-term diet trends. The guiding hypothesis was that as animals matured, lipid composition would reflect the transition from detrital/scavenging feeding modes in juveniles to largely predatory behavior in adults. Potential diets analyzed thus included both suspended particulates, surface sediments at collection sites and A. borealis. Eggs collected opportunistically at several stages of development were included to identify lipids transferred from adults to eggs and to follow their retention by developing embryos during maturation. The objective was to use lipid proxies in $N$. heros and its developing embryos to trace diet patterns across whelk age categories together with CSIA to provide insight into energy transfer in this polar shelf environment. 


\section{MATERIALS AND METHODS}

\subsection{Sample collection and preparation}

Northern Neptune whelks Neptunea heros and their primary prey, the northern clam Astarte borealis, were collected from the Northern Chukchi shelf during the Chukchi Offshore Monitoring in a Drilling Area-Chemical and Benthos (COMIDA-CAB) cruise in August 2012. Epibenthic otter trawls of $10 \mathrm{~min}$ duration were used to collect invertebrates at adjacent sites (Fig. 1). Shell lengths of whelks were measured, and animals were grouped into 4 size classes based on shell size: $4-6,6-8,8-10$ and $>10 \mathrm{~cm}$. Shells were removed and dissection was conducted aboard the ship. Foot muscle from multiple animals across binned size classes ( $\mathrm{n}=4-8$ per size class) were combined for analysis. In addition, several individual adult females with eggs excised were dissected and their foot muscle wrapped in precombusted foil and immediately frozen in liquid nitrogen $\left(\mathrm{LN}_{2}\right)$ and stored until analysis. Eggs were opportunistically collected at 3 stages of development for analysis including internal eggs sacs dissected from gravid females (internal), newly attached egg cases on adult shells at early stages of development (external-fresh) and egg cases near hatch (external-mature). For processing, external egg cases were carefully cleaned of external material and frozen in $\mathrm{LN}_{2}$ for analysis. For $A$. borealis, adductor muscle tissues of 8 animals were dissected from shells $(3-4 \mathrm{~cm})$ and tissue was pooled before storage in $\mathrm{LN}_{2}$. Suspended particulate organic matter (POM), representing potential dietary material, was obtained from bottom waters $(35 \mathrm{~m})$ using pre-cleaned Tygon tubing and a Masterflex peristaltic pump. Whole water was collected in carboys and filtered in a closed system onto pre-combusted $\left(450^{\circ} \mathrm{C}, 4 \mathrm{~h}\right)$

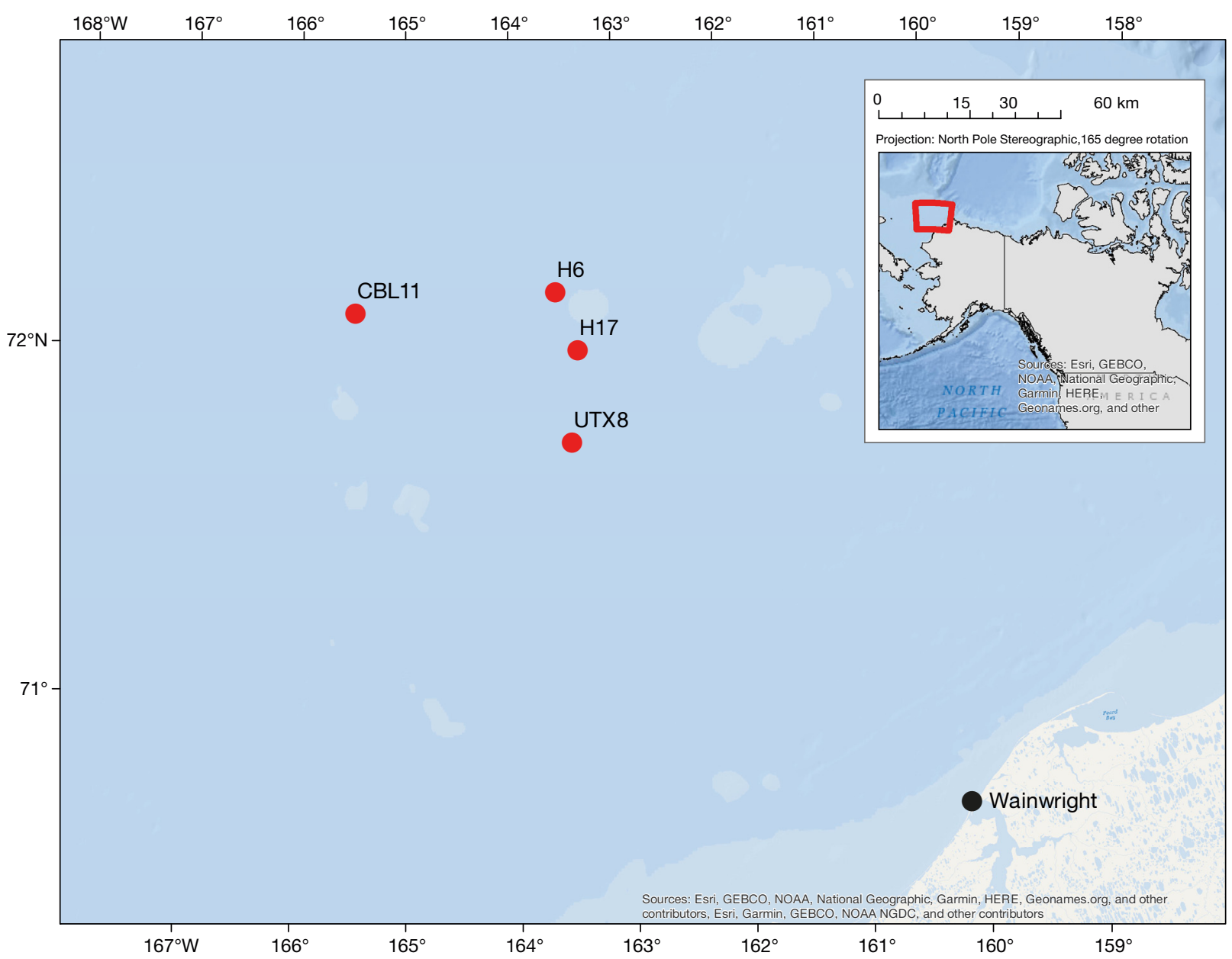

Fig. 1. Chukchi Sea, showing the 4 station locations (red dots) during the August 2012 cruise and sites where Neptunea heros, Astarte borealis, particulate organic matter filtration and surface sediments were collected. Wainwright (black dot) included for geographic orientation 
Whatman glass fiber filters for lipid and particulate organic carbon (POC) analysis; filters were stored frozen at $-80^{\circ} \mathrm{C}$ until analysis. Undisturbed surface sediment $(0-1 \mathrm{~cm})$ for comparison was sampled adjacent to trawl sites using a Van-Veen sampler (Fig. 1) with sediments immediately frozen $\left(-20^{\circ} \mathrm{C}\right)$ and stored in pre-cleaned plastic I-Chem jars with Teflon-lined screw caps. Prior to lipid extraction and OC determination, sediments were lyophilized and thoroughly homogenized. OC content (after $\mathrm{CaCO}_{3}$ removal by acidification with $1 \mathrm{~N} \mathrm{HCl}$ ) of POM and sediments was measured with an Exeter Analytical 440-XA Elemental Analyzer using standard protocols (EPA method 440; Zimmerman et al. 1997).

\subsection{Lipid extraction and analysis}

Total lipids were extracted from tissues, POM and surface sediments using standard protocols with a mixture of hexane:acetone $(1: 1,35 \mathrm{ml})$ at $80^{\circ} \mathrm{C}$ for 30 min using a MARS microwave-assisted extraction system (CEM Corporation) as previously described (Belicka et al. 2004, Harvey et al. 2014). Prior to extraction, $5 \alpha$-cholestane (Sigma-Aldrich) and nonadecanoic acid (Sigma-Aldrich) were added and served as internal standards for the quantification of sterol and fatty acid fractions, respectively. Following extraction, total lipids were filtered through pre-cleaned combusted $\left(4 \mathrm{~h}\right.$ at $450^{\circ} \mathrm{C}$ ) glass wool and combined with 2-4 ml hexane:acetone (1:1) rinses of the extraction vessel and the solvent removed by rotary evaporation. Total lipid extracts were then hydrolyzed with a solution of $0.5 \mathrm{~N} \mathrm{KOH}$ in methanol:water (7:1 v/v) at $70^{\circ} \mathrm{C}$ for $30 \mathrm{~min}$. Sterols were partitioned 3 times with a mixture of hexane:diethyl ether (9:1) and combined. The remaining hydrolyzed mixture was acidified with $\mathrm{HCl}$ to $\mathrm{pH}<2$ and fatty acids partitioned with hexane: diethyl ether (9:1). Total neutral products including sterols were derivatized with bis(trimethylsilyl)trifluoroacetamide (BSTFA) amended with $25 \%$ pyridine at $50^{\circ} \mathrm{C}$ for 15 min to form the trimethylsilyl products. Fatty acids were analyzed as the fatty acid methyl esters (FAMES) following derivatization with $\mathrm{BF}_{3}$ in $\mathrm{MeOH}$.

Neutral lipid products including sterols together with FAMES were separated and quantified by capillary gas chromatography (GC) with an Agilent 6890N Network GC System equipped with a J\&W Scientific DB-5MS fused silica column (60 m length, $0.32 \mathrm{~mm}$ i.d., $0.25 \mathrm{~m}$ film thickness) and flame ionization detection. Derivatized samples without further purification were injected in splitless mode and in- jector temperature of $250^{\circ} \mathrm{C}$ with hydrogen as the carrier gas. The oven temperature was ramped at $15^{\circ} \mathrm{C} \mathrm{min}^{-1}$ to $120^{\circ} \mathrm{C}$ and then $3.5^{\circ} \mathrm{C} \mathrm{min}^{-1}$ to $300^{\circ} \mathrm{C}$ before holding at $300^{\circ} \mathrm{C}$ for $20 \mathrm{~min}$. Lipids were identified with an Agilent 7600 Series GC System coupled to an Agilent 5975 Network Mass Selective Detector (MS) operated in electron ionization mode. The column and temperature program for the GCMS is similar to that described above with helium as the carrier gas. Dimethyl disulfide adducts were also prepared and analyzed by GC-MS to assign double bond position for monounsaturated fatty acids (MUFAs) (Nichols et al. 1986). Analytical precision of repeated analysis for all tissues and sediments averaged $\pm 12.6 \%$.

\subsection{Isotopic analysis of sterols}

CSIA of carbon in individual sterols was measured in lipid extracts from $N$. heros foot muscle, A. borealis adductor muscle and single samples of POM and site sediments. Analysis was performed with a GC IsoLink and TRACE GC ULTRA chromatograph equipped with a split/splitless injector and interfaced via a combustion furnace (at $960^{\circ} \mathrm{C}$ ) to a Thermo Fisher DELTA V Plus stable isotope mass spectrometer run in a continuous flow mode. The column and temperature program for the GC-IRMS is similar to that described above with hydrogen as the carrier gas. The $\mathrm{CO}_{2}$ reference gas was automatically introduced into the IRMS in a series of pulses before and after each sequence of 5 samples, and data are reported in per mil (\%) relative to the Vienna Pee Dee Belemnite (V-PDB) standard. A $\mathrm{C}_{21} n$-alkane standard reference material with known isotopic composition was injected in triplicate at the beginning and end of every 5 samples in order to evaluate instrument precision and reproducibility. Each experimental sample was analyzed in triplicate and peaks with values greater than $0.5 \mathrm{~V}$ were recorded and considered to guarantee the accuracy of results. To correct for additional carbon atoms on sterols during the formation of trimethylsilyl derivatives, cholesterol was used as a standard reference material (SigmaAldrich) and analyzed before and after derivatization with BSTFA to determine the isotopic offset.

\subsection{Statistical analysis}

Principal component analysis (PCA) was performed using MATLAB based on weight percent composition 
(as relative abundance normalized to dry weight) of individual sterols in $N$. heros adults, eggs and their corresponding food sources (POM, surface sediments and $A$. borealis tissues). By default, MATLAB centers the data and uses the singular value decomposition (SVD) algorithm for analysis. The output includes the coefficients (loadings) of each variable and score values, which were used in the projection of each data point into the principal component (PC) space. Results here utilize the coefficients to better describe the suite of sterols contributing to the variance of the first $2 \mathrm{PCs}$ which in sum described at least $70 \%$ of total variation. Sterols with coefficients (loadings) of 0.25 or -0.25 (out of a total possible 1 or -1) or higher were considered significant contributors to a PC. Zero values were set as 10 times the GC-MS limit of detection to account for statistical

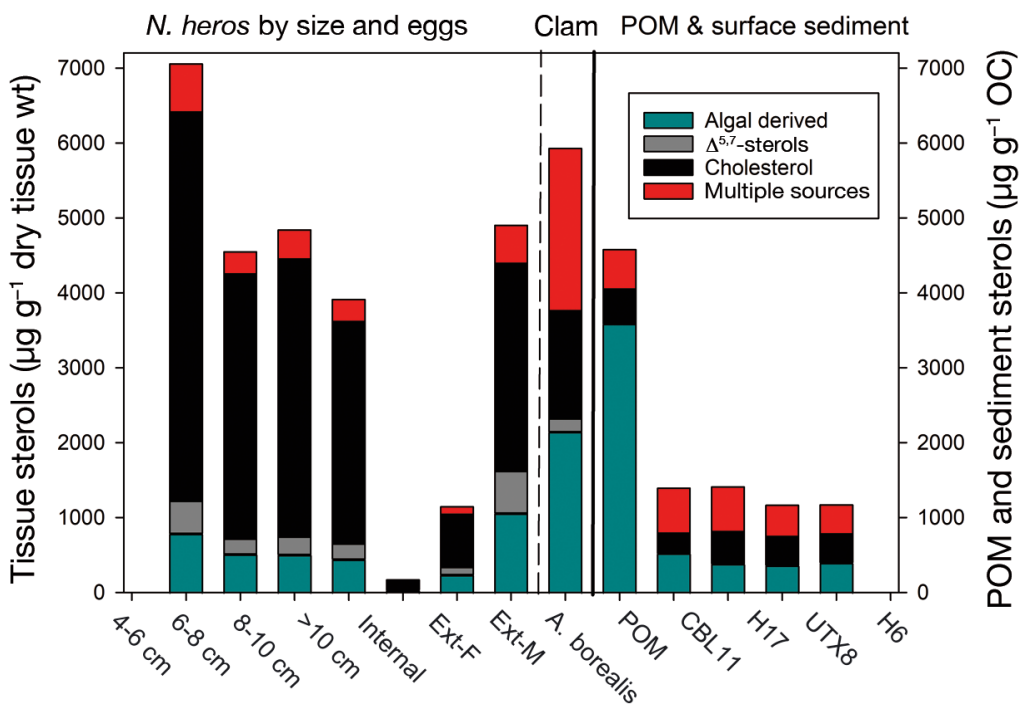

Fig. 2. Total concentration and abundance of sterols in Neptunea heros, its eggs at 3 developmental stages, clam Astarte borealis muscle tissue (as mg $\mathrm{g}^{-1}$ dry tissue weight) and suspended particulate organic matter (POM) and surface sediments (as $\mathrm{mg} \mathrm{g}^{-1}$ organic carbon [OC]) at 4 sites where animals were collected. Eggs are designated as internal egg mass (Internal), eggs associated with recently attached egg cases (Ext-F) and mature egg cases near hatch (Ext-M)

significance. As animal tissues are dominated by cholesterol $(>70 \%)$, it was excluded from analysis to allow other sterols to be compared. The goal of PCA was to use unstructured source assignments to reduce the number of variables useful to distinguish potential feeding relationships and metabolism across animals of increasing age, eggs and food sources.

\section{RESULTS}

\subsection{Sterols in Neptunea heros and developing eggs}

A diverse suite of 20 sterols were observed across the size classes of Neptunea heros and developing eggs, representing multiple dietary sources plus apparent de novo synthesis (Fig. 2, Table 1). Summed sterol concentrations in $N$. heros ranged from 3.88$7.86 \mathrm{mg} \mathrm{g}^{-1}$ dry tissue weight with cholesterol $\left(\mathrm{C}_{27} \Delta^{5}\right)$ as the dominant sterol $(72-79 \%)$ in animals followed by 3 algal-derived sterols seen as 24-methylcholesterol $\left(\mathrm{C}_{28} \Delta^{5}\right)$, brassicasterol $\left(\mathrm{C}_{28} \Delta^{5,22}\right)$ and the 24-methylcholesta-5, 24(28)-dienol $\left(\mathrm{C}_{28} \Delta^{5,24(28)}\right)$ (Fig. 2, Table 1). Together with small amounts of additional algalderived sterols observed, $N$. heros tissues across all size classes and individuals contained $11-15 \%$ as algal-derived structures. In addition, $\Delta^{5,7}$-sterols were only abundant in $N$. heros foot muscle and included 7-dehydrocholesterol as well as 24-norcholesta-5,7, 22-trienol $\left(\mathrm{C}_{26} \Delta^{5,7,22}\right), 24$-methylcholesta-5,7-dienol
$\left(\mathrm{C}_{28} \Delta^{5,7}\right)$, 24-methylcholesta-5, 7, 22-trienol $\left(\mathrm{C}_{28} \Delta^{5,7,22}\right)$, 24-methylcholesta-5, 7, 24(28)-trienol $\left(\mathrm{C}_{28} \Delta^{5,7,24(28)}\right)$, 24-ethylcholesta-5,7-dienol $\left(\mathrm{C}_{29} \Delta^{5,7}\right)$ and 24-ethylcholesta-5, 7, 22-trieneol $\left(\mathrm{C}_{29} \Delta^{5,7,22}\right)$ (see Table 1). The distribution was surprisingly consistent; $N$. heros of all ages (i.e. sizes) showed similar sterol distributions derived from multiple sources, with the largest whelks $(>10 \mathrm{~cm})$ having tissues only slightly lower in total sterols.

Sterol composition in eggs collected opportunistically and representing 3 developmental stages of Neptunea reflected multiple origins and differed from adult tissues (Fig. 2, Table 1). As seen for adults, cholesterol was the dominant sterol, accounting for $59-63 \%$ of total sterols in eggs across all 3 stages. Algal-derived sterols were common and higher than seen in adult muscle tissues, ranging from $21-24 \%$ of the total sterols. Diatom-derived sterols were the major component of algal sterols observed; in particular, brassicasterol and the $\mathrm{C}_{28} \Delta^{5,24,(28)}$, which together accounted for about twice the amount seen in $N$. heros adults. Sterols were highly conserved during egg maturation and also showed a large increase in weight-based concentrations in external versus internal egg masses. Dry weight normalized concentrations increased substantially during maturation, with late-stage eggs having almost 30 -fold greater sterol content compared to internal egg masses of gravid females (Fig. 3, Table 1). Given the consistent distribution, this suggests that structural 


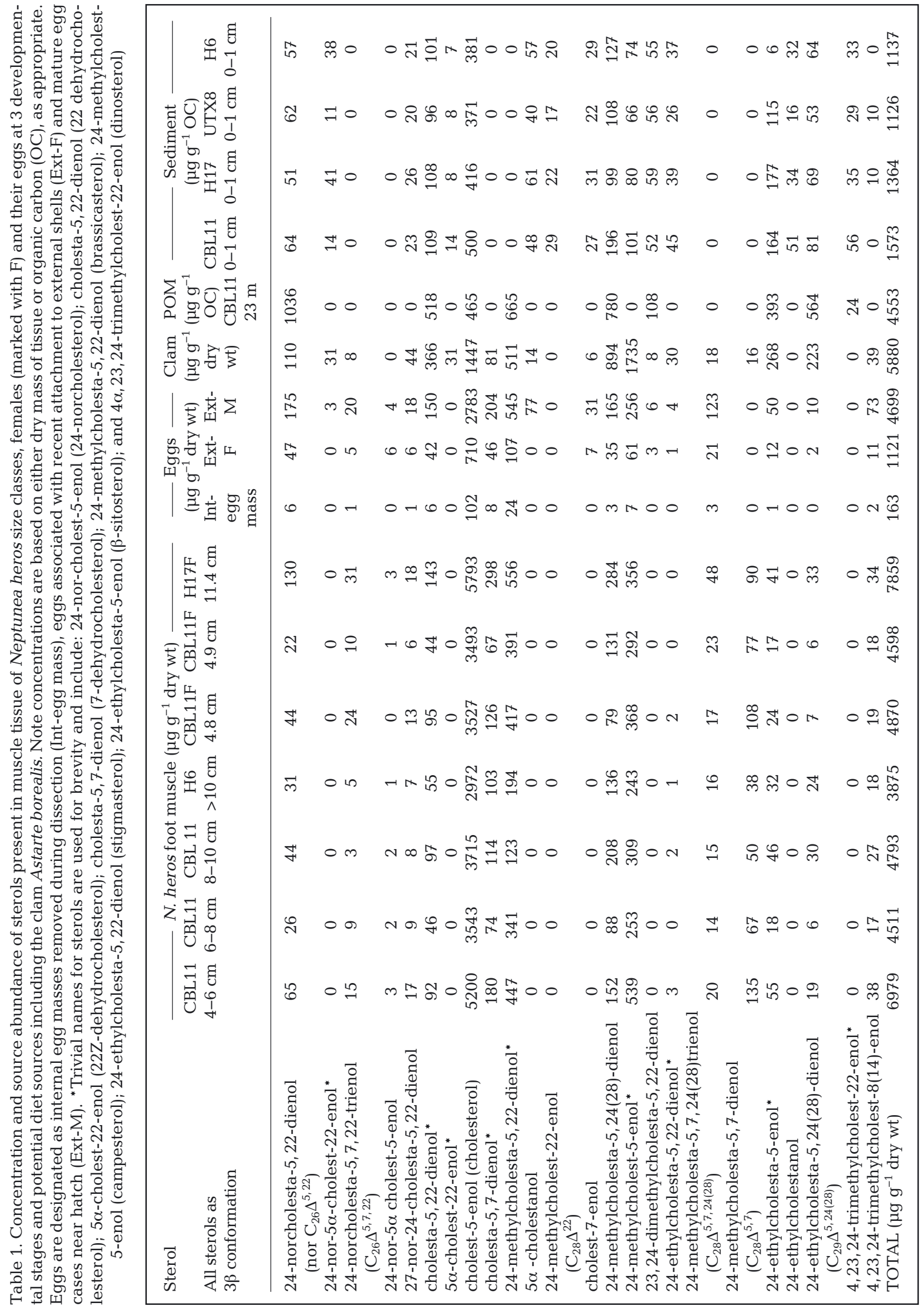




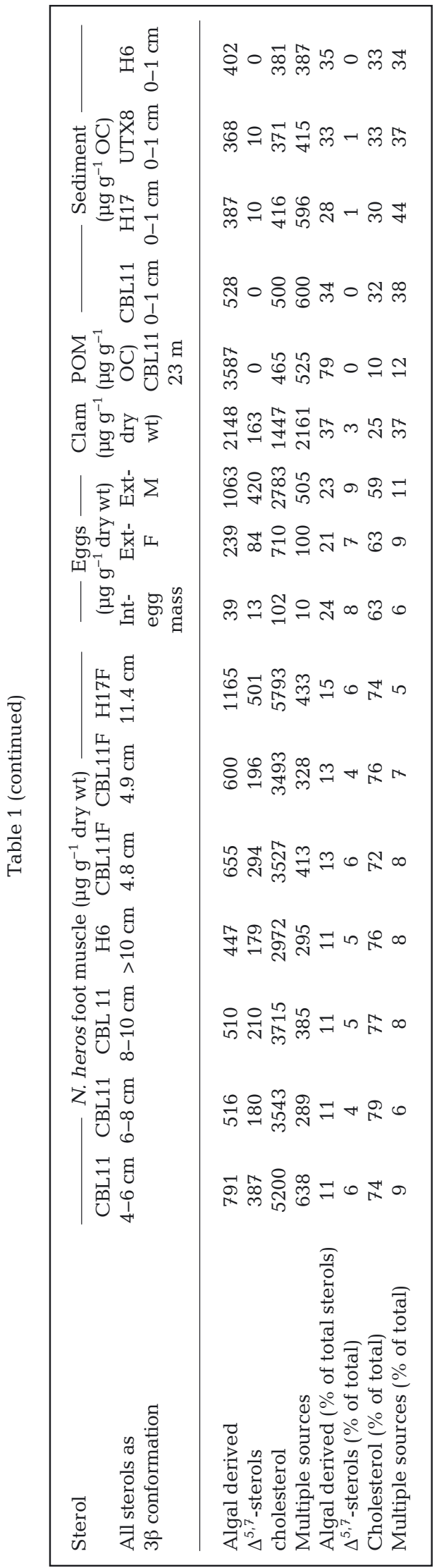

sterols were highly conserved while other cellular compartments were metabolically utilized during embryogenesis.

\subsection{Sterols across potential diets}

In the potential prey Astarte borealis, 21 sterols were observed in tissues with a summed concentration of $5.88 \mathrm{mg} \mathrm{g}^{-1}$ dry muscle for the composite sample. While cholesterol remained an important component as seen in $N$. heros, clam tissues contained higher amounts of algal-derived sterols than whelks; in particular, the 24-methyl cholesterol and the $\mathrm{C}_{28} \Delta^{5,24(28)}$. Sterols with structures that might have multiple (animal or plant) origins were also higher than seen in $N$. heros and accounted for $37 \%$ of the sterols observed in filter feeding clams.

As might be expected for this dynamic polar shelf system, sterols present in suspended particles (POM) differed from underlying sediments and animals (Table 1). Four algal sterols accounted for over half of the total sterols seen in POM, including 24-norcholesta-5, 22-dienol, $\left(\mathrm{C}_{26} \Delta^{5,22}\right)$, brassicasterol, 24-methylcholesta-5, 24(28)-dienol, plus $\mathrm{C}_{29} \Delta^{5,24(28)}$. These algal sterols were coincident with those elevated in both benthic invertebrates despite the absence of $\Delta^{5,7}$ sterols in particles. Surface sediments at the 4 sites examined showed a more diverse sterol distribution, including expected algal-derived sterols as the major contributors dominated by diatoms but also dinosterol, representing dinoflagellates (e.g. Harvey et al. 1988). Sediment sterol concentrations (based on OC) were largely uniform, ranging from $1.14-1.57 \mathrm{mg} \mathrm{g}^{-1} \mathrm{OC}$. Cholesterol was seen in significant concentrations along with a number of algal sterols plus the plant-derived $\beta$-sitosterol $\left(\mathrm{C}_{29} \Delta^{5}\right)$ as an important contributor (Fig. 2). Sterols with several possible origins as animals or plant and defined as multiple sources ranged from $34-44 \%$ of sediment sterols.

\subsection{PCA of sterols}

Initial comparisons of sterol patterns across $N$. heros size classes showed that cholesterol dominated the variance in mollusks, eggs, sediments and particles. Accounting for up to $78 \%$ of the total sterols in adult whelks and up to $63 \%$ of eggs, cholesterol defined animals versus their food sources. To better explore diagnostic structures and potential dietary linkages, it was removed from subsequent 

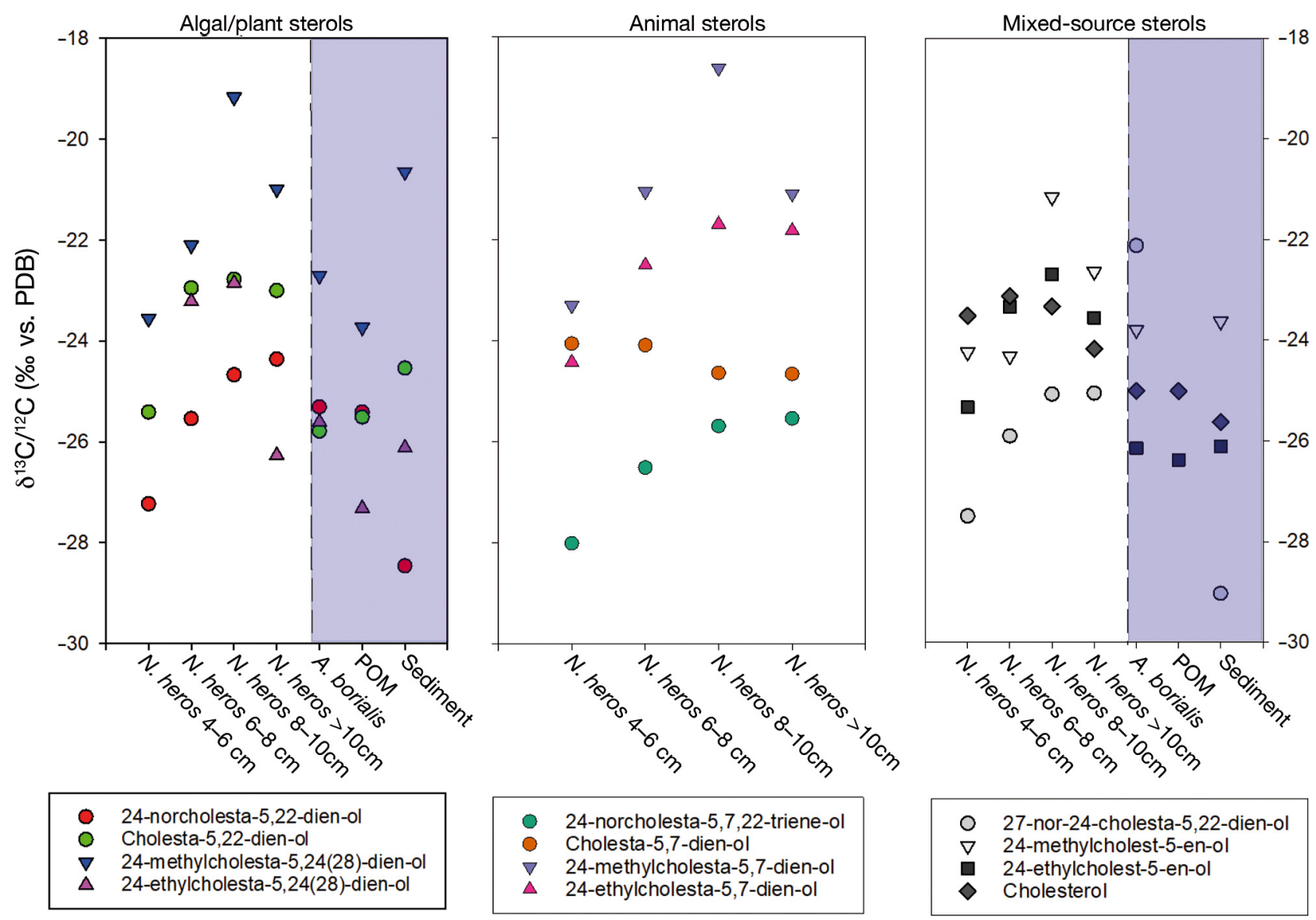

Fig. 3. Compound-specific carbon isotopic values (as $\delta C$ ) of major sterols present in Neptunea heros size classes and potential diets. Sterols are grouped based on most likely sources (algal, animal or mixed) and include major sterols observed. Error bars are excluded for clarity but averaged $\pm 0.26 \%$ SE. Individual values and standard error for replicate measures of all sterols are provided in Table S1. POM: suspended particulate organic matter

analysis and sterol composition rescaled. Remaining sterols in $N$. heros across multiple size classes versus potential diets (with cholesterol excluded) are shown in Fig. 4. PCA results showed that 2 PCs could describe $79 \%$ of the variance among whelks and potential diets with animals across all size classes clustering closely (Fig. 4). Potential food sources showed 2 major clusters with sediments across the

Fig. 4. Principal component analysis based on sterol composition present across Neptunea heros binned across 4 size classes and major diet sources. Diets include the clam Astarte borealis adductor muscle, surface sediments at 3 locations where animals were observed and suspended particles (POM). PCA1 variance $(46 \%)$ was primarily driven by presence of algal sterols, especially those from diatoms. PCA2 variance $(33 \%)$ reflected the substantial presence of $\Delta^{5,7}$-sterols in clams that were not seen in whelks or potential diets

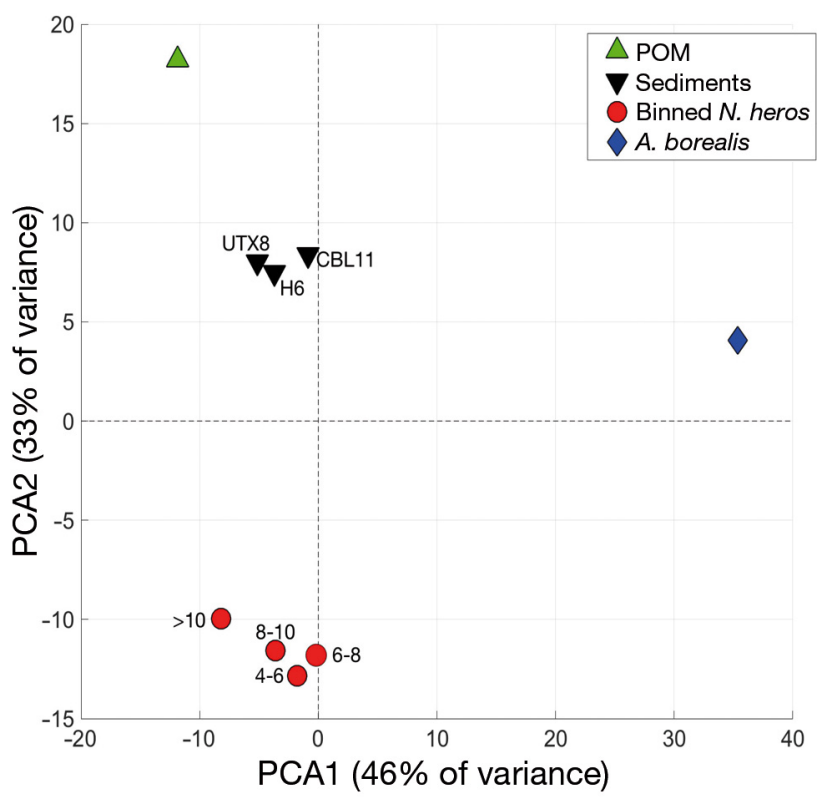


4 sites as one cluster and separated from water column particles. As might be anticipated, PC1 was largely defined by the relative abundance of algalderived sterols, in particular the $\mathrm{C}_{26} \Delta^{5,22}, \mathrm{C}_{27} \Delta^{5,22}$, brassicasterol, $\mathrm{C}_{28} \Delta^{5,24(28)}$ and 24-ethylcholesta5,24(28)-dienol $\left(\mathrm{C}_{29} \Delta^{5,24(28)}\right)$, which isolated clams from sediments and POM (Fig. 4). The isolation of $A$. borealis in PC2 from sediments and particles was largely driven by 24-methylcholesterol, dinosterol $(4 \alpha, 23,24$-trimethylcholest-22-enol, diagnostic of dinoflagellates) and $\beta$-sitosterol, a plant sterol identified in all samples but enhanced in sediments and particles. A second analysis conducted with the inclusion of eggs showed very similar results, with close clustering of eggs and animals driven by the overlap of several $\Delta^{5,7}$ sterols unique to whelks (data not shown; see Table1).

\section{4. $\delta^{13} \mathrm{C}$ values of sterols in animals and potential diets}

CSIA for major sterols present in $N$. heros and potential diets and showed a range of values dependent on source, structure and animal size class (Fig. 3, Table S1 in the Supplement at www.int-res.com/ articles/suppl/m673p069_supp.pdf). Algal sterols present in muscle tissues across $N$. heros size classes, including the $\mathrm{C}_{26} \Delta^{5,22}, \mathrm{C}_{27} \Delta^{5,22}$ and $\mathrm{C}_{28} \Delta^{5,24,28}$, showed a consistent trend to heavier values $(+2.61 \pm 0.24 \%$ o) with increasing size (and age), particularly compared to values seen in POM, clams and sediments. A similar trend was seen for several specific $\Delta^{5,7}$ derivatives, the best example being the $\mathrm{C}_{26} \Delta^{5,7,22}$ sterol which paralleled the depletion pattern seen in algal sources $\left(\mathrm{C}_{26} \Delta^{5,22}\right)$ and showed a $2.47 \%$ shift with increased size and presumably age (Table S1). In contrast, cholesterol isotopic values showed only minor shifts $(<0.66 \%$ ) with increasing size for $N$. heros with a similar pattern seen in its metabolically modified derivative $\left(\mathrm{C}_{26} \Delta^{5,7}\right)$. Potential sources of dietary cholesterol in clams, POM and sediment were similar or slightly more depleted by comparison (Fig. 3). For mixed-source sterols, both trends were seen, with one sterol (27-nor-24 cholesta-5,22-dienol) showing a consistent pattern of depletion with in- creasing size, yet algal sterols and others were more variable (Fig. 3). Other mixed-source sterols, such as $\beta$-sitosterol, showed remarkably consistent values across clams, sediment and POM compared to whelks.

\subsection{Fatty acids in $N$. heros and developing eggs}

Fatty acids represent a metabolically active lipid pool, and summed concentrations in whelk foot muscle ranged from 4.53-6.42 $\mathrm{mg} \mathrm{g}^{-1}$ dry wt (Fig. 5, Table S2) Tissue total fatty acid content showed only small variations across increasing class size. Polyunsaturated fatty acids (PUFAs) accounted for a major fraction of the total fatty acids in adults (47-66\%) and eggs (37-46\%), with PUFA signatures mainly comprising C20:4n-3, C20:5n-3 and C22:2 acids. These highly unsaturated dietary acids appear to be derived largely from diatoms and were highly conserved with eggs during development as a fraction of total fatty acids (Table S2). MUFAs (mainly C18: and C20:1 isomers) and saturated fatty acids (mainly C16:0 and C18:0) each contributed a similar fraction to total fatty acids. Branched acids (as iso and anteiso $\mathrm{C}_{15}$ and $\mathrm{C}_{17}$ forms) accounted for $2-4 \%$ of the total fatty acids seen in $N$. heros size classes and individual females and their eggs.

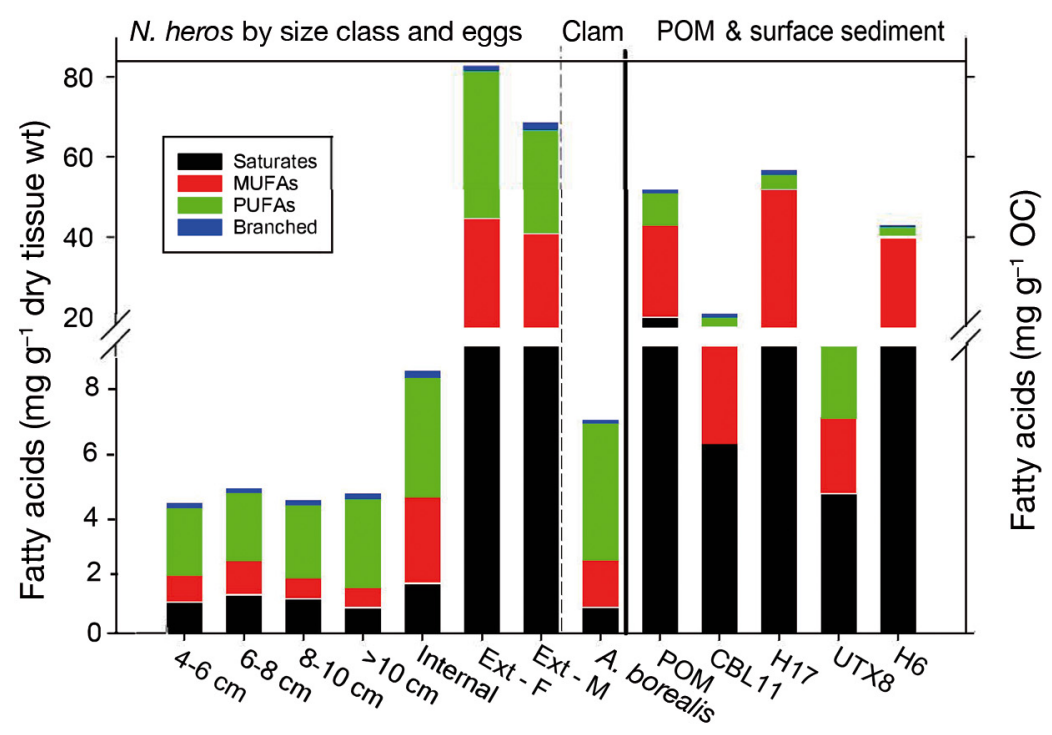

Fig. 5. Total concentration and abundance of total free and esterified fatty acids in Neptunea heros, its eggs at developmental stages, clam Astarte borealis muscle tissue (as $\mathrm{mg} \mathrm{g}^{-1}$ dry tissue weight), suspended particulate organic matter (POM) and surface sediments (as $\mathrm{mg} \mathrm{g}^{-1}$ organic carbon [OC]) at 4 sites where animals were collected. Eggs are designated as internal egg mass (Internal), eggs associated with recently attached egg cases (Ext-F) and mature egg cases near hatch (Ext-M) 
Similar to sterol concentrations in adults, fatty acids in $N$. heros eggs over the 3 developmental stages showed a consistent distribution, with low amounts of saturated acids and higher MUFAs compared to animal tissues (Fig. 5). Algal-derived PUFAs transferred from adults were an important component, particularly the diatom-derived C20:5n-3, which was abundant in individual females. For all 3 egg stages, PUFAs accounted for the largest fraction of total fatty acids and remained a major fraction during development. As with sterols, the relative concentration of fatty acids increased substantially in developing external eggs compared to internal egg masses, suggesting that lipids as a biochemical fraction were conserved as eggs matured.

\subsection{Fatty acids among potential diets}

In $A$. borealis, total fatty acid concentrations in body tissues (7.41 $\mathrm{mg} \mathrm{g}^{-1}$ dry wt) were only slightly higher than that seen for equivalent $N$. heros tissues (Fig. 5). Algal-derived C20:5n-3 and C22:6n-3 acids were primary contributors to total fatty acids present in clams, with PUFAs accounting for almost twothirds of total acids present. MUFAs, particularly C16:1 and C18:1n-9, accounted for $22 \%$ of total fatty acids. Saturated (13\% of total) and branched fatty acids ( $1 \%$ of total) were lower in $A$. borealis than $N$. heros, with branched acids similar in abundance.

Water column particles represent the major food source for filter feeding clams, and total fatty acids in suspended particles were significant at $52.16 \mathrm{mg} \mathrm{g}^{-1}$ OC (Fig. 5, Table S2). Algal-derived PUFAs were the important contributors to the total fatty acids of POM, reflecting fresh algal material largely derived from diatoms and in agreement with sterol distributions. Saturated fatty acids (mainly C16:0 and C18:0) and MUFAs (mostly C16:1) accounted for 39 and $44 \%$ of the total fatty acid concentration, respectively. Branched fatty acids (largely $\mathrm{C}_{15}$ iso and anteiso forms) in POM accounted for $2 \%$ of the total and were similar to animal tissues.

The 4 surface sediments examined showed variable concentrations and expected lower amounts than seen for particles and ranged about 4-fold among the sites. Distributions of fatty acids were more varied at one site (UTX8) which contained substantial amounts of recent algal material as PUFAs. Saturated fatty acids (mainly C16:0) were similar across sites at $29-35 \%$ of total acids present, with a larger variation seen in the fraction of MUFAs (mainly C16:1). Branched fatty acids also varied, ranging from $1 \%$ of fatty acids at $\mathrm{H} 6$ to $5 \%$ of total acids at CBL11.

\section{DISCUSSION}

\subsection{Sterols as trophic markers in Neptunea heros and its potential diets}

On the broad, shallow continental shelf of the Chukchi Sea, substantial amounts of labile autochthonous carbon reach the benthos, including diagnostic lipids that can be traced throughout the food chain. The 21 sterols in the clam Astarte borealis revealed a diet derived mainly of phytodetritus despite seasonal ice cover (Grebmeier 2012). Diatoms (Gladu et al. 1991, Barrett et al. 1995), particularly Thalassiosira sp., are known producers of the $\mathrm{C}_{28} \Delta^{5,24(28)}$, which was abundant in the whole body and muscle tissue of $A$. borealis. Small amounts were also seen in Neptunea heros, reflecting pathways for direct ingestion of detritus or consumption by clams and subsequent incorporation. This balance of direct versus secondary incorporation is supported by the shift seen in isotopic abundance for several sterols, with lower depletion seen with increased animal size classes. For example, diatom-derived brassicasterol accounted for a significant fraction of the total sterols in clam adductor muscle but was only present in trace amounts of $N$. heros. Concentrations of dehydrocholesterol and brassicasterol in POM were similar to values previously reported for Chukchi Sea particles (Belicka et al. 2004) and correspond to concentrations seen in bivalves (e.g. Goad 1978).

Other sterols including the 24-methyl cholesterol, $\beta$-sitosterol and the $\mathrm{C}_{29} \Delta^{5,22}$ observed in $N$. heros have multiple dietary origins and showed varied isotopic signatures. These sterols can represent vascular plant signatures and have been used as tracers of terrestrial-derived organic matter in Arctic rivers, particles and marine sediments (Belicka et al. 2004, Fahl \& Nöthig 2007, Vonk et al. 2008). Although it is tempting to assign a direct incorporation pathway, some caution is warranted for these field collections; it is possible that algal sterols may have been incorporated in tissues through secondary routes such as clam predation. There are also rare exceptions that marine phytoplankton could be the source of these sterols in polar systems. For example, at multiple sites in Antarctica, $\beta$-sitosterol was the dominant sterol found in sea-ice diatom communities (Nichols et al. 1990) and was also seen in surface sediment from Ace Lake, Antarctica (Volkman 1986). This 
sterol has also been seen in POM from the Chukchi Sea shelf (Belicka et al. 2004) and was assigned as being of phytoplankton origin based on the absence of a vascular plant source and the concurrent presence of significant diatom biomarkers. Whether these sterols arise from POM or clams from the Chukchi shelf, their presence in $N$. heros points to dietary incorporation. Isotopic values for $\beta$-sitosterol were very similar for clams, sediment and POM (range -26.11 to $-26.38 \%$ ), which argues for a single source but does not allow direct consumption or clam predation of $N$. heros to be distinguished.

Although $A$. borealis are mainly reported as benthic suspension feeders with a specialized siphon for extracting food particles from seawater, Hummel (1985) and others (e.g. Legeżyńska et al. 2014) have suggested they may also act as deposit feeders. The sterol signature in muscles of $A$. borealis argues for suspension feeding as the primary route in Chukchi shelf waters, where near-bottom currents drive sediment resuspension and lateral transport along the broad, shallow continental shelf (Johnson et al. 1988). Diagnostic algal-derived sterols are also seen in $N$. heros tissues at somewhat lower amounts and may reflect a combination of a diet transition for $N$. heros during maturation towards predation as well as removal during translocation of algal-derived sterols to eggs (Table 1). In either case, it is apparent that whelks rely on algal sterols plus the biosynthesis or metabolic modification of sterols seen as the $\Delta^{5,7}$ structures obtained directly or through predation to provide structural lipids for membrane integrity. These lipids are also transferred to eggs, with the consistent distribution suggesting that there is little selection of actual structures during transfer from adults.

As a predator, adult $N$. heros have the potential to incorporate and store sterol signatures through trophic transfer. One example is the major sterol campesterol seen in A. borealis that was also abundant in surface sediment (16-20\% of the total sterols) but at the time of sampling was absent in POM. If $N$. heros sterol composition reflects a shift in feeding strategy with size as suggested, the presence of campesterol across all size classes suggests multiple modes of trophic transfer, with sediment uptake associated with scavenging or detrital feeding of smaller animals and direct incorporation by predation for adults. While campesterol in $N$. heros likely results from predation on bivalves, juvenile whelks may have consumed material directly as detrital material; this is supported by the absence of shell fragments seen in smaller $N$. heros guts during dissection but the abundant presence of sediment. Alternatively, the con- sumption of infauna prey may have allowed sterol transfer to whelks, and predation on polychaetes as an alternate route has been observed (Taylor 1978, Shimek 1984, Fujinaga \& Nakao 1999). Further, recent reports of the deposit feeders Nephthys ciliata and Praxillella gracilis on the Chukchi shelf could provide additional food and sterol sources (Dunton et al. 2014). If feeding activities are similar to that seen in the Bering Sea to the south (Shimek 1984), adult $N$. heros from the Chukchi shelf are likely to feed as predators rather than scavengers. Recent analysis of $\delta^{15} \mathrm{~N}$ value in foot muscle corroborates the observed lipid distribution and their higher trophic position than many benthic invertebrates (McTigue \& Dunton 2014), suggesting that the presence of campesterol in larger adults was incorporated via predation rather than direct sediment ingestion.

The complexity of dietary sources consumed and those metabolically modified by $N$. heros is mirrored by the diverse suite of 20 sterols observed (Table 1). While contributions from phytoplankton, either directly or secondarily through predation on other invertebrates, are significant, a number of metabolically derived algal sterols (desaturation at $\mathrm{C}_{7}$ ) were present as well as $\Delta^{5,7}$-sterols. For example, the $\mathrm{C}_{28} \Delta^{5,7,24(28)}$ in foot muscle likely originates from the diatom-derived $\mathrm{C}_{28} \Delta^{5,24(28)}$ through desaturation at delta 7. Similarly, 24-norcholesta-5, 7,22-trienol $\left(\mathrm{C}_{26} \Delta^{5,7,22}\right)$, 24-methylcholesta-5,7,22-trienol $\left(\mathrm{C}_{28} \Delta^{5,7,22}\right)$ and 24-ethylcholesta-5, 7, 22-trienol $\left(\mathrm{C}_{29} \Delta^{5,7,22}\right)$ were found in tandem with the diatom markers $\mathrm{C}_{26} \Delta^{5,22}, \mathrm{C}_{28} \Delta^{5,22}$ and $\mathrm{C}_{29} \Delta^{5,22}$ in foot muscle. In $N$. heros, the $\Delta^{5,7}$-sterols accounted for $22-27 \%$ of the total sterol composition, comparable to summed $\mathrm{C}_{26}-\mathrm{C}_{29} \Delta^{5,7}$ sterols reported in bivalves reliant on filtration including the clam Cerastoderma edula (Khan \& Goad 1983), the oysters Crassostrea giga (Gordon \& Collins 1982) and C. virginicia (Teshima \& Patterson 1981) and the mussel M. modiulus (Khan \& Goad 1983). This consistent presence of the $\mathrm{C}_{26}-\mathrm{C}_{29} \Delta^{5,7}$-sterols in other mollusks which are not predatory plus their presence in muscle tissues across juvenile to largest adults suggests that $N$. heros does not directly incorporate these compounds from predation activities. Instead, whelks appear to either modify algal-derived sterols obtained through trophic transfer or may biosynthesize $\Delta^{5,7}$-sterols de novo. Given the caveat that these are field collections, the observation of significant amounts of both algal-derived and structurally related $\Delta^{5,7}$-sterols in whelk eggs appears to be a direct consequence of the transfer of both dietary and modified sterols from adults during reproduction. Although not previously reported in this species, the ability of marine gastropods to synthesize 
$3 \beta$-sterols de novo has been observed in other species including Neptunea antiqua and Buccinum undatum (see Voogt 1983 and references therein). The $\delta^{13} \mathrm{C}$ values obtained for $\mathrm{C}_{27} \Delta^{5,7}$ in foot muscle $(-24.4 \pm 0.3 \%$ o) for $N$. heros were similar across all size classes; this indicates consistent fractionation during metabolism and/or an isotopically invariant diet source. It also suggests that $N$. heros have the ability to biosynthesize $3 \beta$-sterols de novo, and particularly $\mathrm{C}_{27} \Delta^{5,7}$. Based on the dominance of structurally related cholesterol $\left(\mathrm{C}_{27} \Delta^{5}\right)$ in foot muscle, it is likely that the $\mathrm{C}_{27} \Delta^{5,7}$ is a product of its dehydrogenation. Isotopic values also suggest that cholesterol is a product of de novo biosynthesis in $N$. heros, as $\delta^{13} \mathrm{C}$ values measured in foot muscle $\left(-23.5 \pm 0.5 \%, \delta^{13} \mathrm{C}_{\mathrm{PDB}}\right.$ mean $\left.\pm \mathrm{SD}\right)$ were tightly coupled across the range of animal shell lengths $(4$ to $>10 \mathrm{~cm})$ in which animals transition to predation with increasing size. Finally, the $\delta^{13} \mathrm{C}$ values of cholesterol in $A$. borealis muscle $(-25.0 \%)$ and POM $(-25.0 \%)$ were slightly enriched relative to $N$. heros foot muscle and suggest isotope fractionation arising through the food chain. To our knowledge, this is the first report of compound-specific carbon isotopic analysis of sterols in both $N$. heros and A. borealis and its use for insight into lipid metabolism in field collections.

\subsection{Fatty acids in Chukchi Sea mollusks, POM and sediment}

Although sterols provide essential source specificity, fatty acids can also provide source information and support that $A$. borealis received a major portion of their food directly from phytodetritus descending to the sea floor. Diatoms are a rich source of the PUFA C20:5n-3 (Volkman et al. 1989, Dunstan et al. 1993) which was abundant in A. borealis adductor muscle. Essential for growth and development (e.g. Mai et al. 1996), this acid is often a major fatty acid sequestered by other bivalves (Isay \& Busarova 1984, Brazão et al. 2003) and is retained in tissues. As consumers of $A$. borealis, $N$. heros appears to directly acquire the C20:5n-3 PUFA, and it is the dominant fatty acid in whelk foot muscle (Table S2). Dinoflagellates are also common in the Chukchi Sea (Belicka et al. 2004) and appear a significant food source as seen from the diagnostic C22:6n-3 acid (e.g. Harvey et al. 1988) as a major fatty acid in N. heros. This does not appear unique; in the clam Astarte sulcate this acid accounted for the major fatty acid observed in muscle tissues (C22:6 as 19-23\% of the total) compared to fatty acids diagnostic of diatoms (C20:5 as
7-9\%) (Olsen et al. 2009). For N. heros, its presence in POM and its likely clam prey would provide for multiple routes for incorporation.

A relatively high unsaturated fatty acid content appears common to a wide range of mollusks, including filter feeding bivalves, herbivorous gastropods and predatory whelks which are consumed (e.g. Nichols et al. 1998). Specific PUFAs support sterol observations for direct lipid incorporation from primary production to higher trophic level consumers in the Chukchi Sea. This includes the C20:4 that has been previously reported among bivalve mollusks and predatory gastropods (Voogt 1983, Isay \& Busarova 1984, Olsen et al. 2009). The C20:4 PUFA accounted for $7 \%$ of the total fatty acid concentrations in the adductor muscle of both $A$. borealis and A. sulcata (Olsen et al. 2009). Similarly, the high relative abundance of C20:4 seen in N. heros (13-18\% of the total) has been argued as being diagnostic of foraminiferal consumption (Legeżyńska et al. 2014) and may reflect secondary accumulation during predation on clams. The absence of specific fatty acids has also proven valuable to argue against dietary incorporation by benthic consumers; for example, invertebrates residing in seagrass communities which showed limited direct consumption (Kharlamenko et al. 2001). One complication to direct comparisons is that the conversion of C20:4 to C22:4 and C20:5 to C22:5 via chain elongation appears possible among several marine invertebrates including starfish Astropecten sp., shrimp Solenocera sp., sea fans Echinoptilum sp., sea anemones Actinoscyphia sp. and annelids such as Hyalinoecia sp. (Jeffreys et al. 2009); yet this mechanism has not been described in marine mollusks despite their widespread reported routes for fatty acid synthesis (Kluytmans et al. 1985). Concentrations of the $\mathrm{C} 22: 4$ in $A$. borealis adductor muscle were similar $(0.4 \%)$ to that seen for A. sulcata $(0.5-0.6 \%)$ (Olsen et al. 2009), with the former showing a higher proportion of $\mathrm{C} 22: 5$ ( $3 \%$ of the total) than the latter $(0.6-0.7 \%$ of the total). Assuming an algal origin, this likely reflects differences in water column communities between the sampled locations (Jarzębski et al. 1985, Morais et al. 2003). The retention of PUFAs in developing eggs has been observed in other gastropods such as nudibranchs, but retention also appears to be speciesspecific (Martínez-Pita et al. 2005). In the case of $N$. heros, algal-derived PUFAs showed a uniform distribution and increased on a weight basis with maturation, suggesting that these fatty acids are tightly retained to provide structural viability for veligers.

Branched fatty acids (mainly $\mathrm{C}_{15}$ and $\mathrm{C}_{17}$ ) diagnostic of bacteria (Kaneda 1991) were seen in POM and 
surface sediments as well as both $A$. borealis and $N$. heros (Table S2). Given that microbial fatty acids comprise a broad suite of diagnostic branched acids (e.g. Harvey \& Macko 1997), a conservative estimate is that bacterial contributions represent $3-4 \%$ of the total fatty acids across POM and sediment samples from the Chukchi Sea. Our observations were consistent with branched fatty acids previously reported in POM and surface sediment from the Chukchi shelf (Belicka et al. 2004) and suggest the passive incorporation of microbial biomass during bivalve feeding. Incorporation of branched fatty acids into both clam and whelk muscle tissues appears to reflect the movement of bacterial signatures through the food chain.

Additional fatty acids with a non-algal origin were also observed in Chukchi Sea mollusks, including C22:2 which is not characteristic of phytoplankton and was absent in POM, yet seen in both $A$. borealis and $N$. heros. Known as non-methylene-interrupted dienoic (NMID) fatty acids, these unusual lipids have been reported in several phyla of marine invertebrates (Coelenterata, Mollusca, Echinodermata and Arthropoda) and in the depot fats of some marine mammals (e.g. Ackman \& Hooper 1973, Budge et al. 2007, Le Grand et al. 2011). The C22 (as well as C20) NMID acids are abundant among different families of marine bivalves (Arcidae, Mytilidae, Ostreidae, Veneridea, Mactridae) with relative amounts (1$21 \%$ of the total polar lipids) reported to vary between species (Zhukova 1991, Kraffe et al. 2004). The biosynthesis of NMID acids in bivalves is hypothesized to rely on conversion of the C16:1 and C18:1 acids via chain elongation and desaturation (Zhukova 1991). While biosynthesis in gastropods remains unclear, many (Klingensmith 1982, Dunstan et al. 1996, Brazao et al. 2003) have observed C22 NMID acids in various species that include $N$. intersculpa and Buccinum sp., and its presence here in $A$. borealis provides a direct dietary source for its accumulation in $N$. heros. C22:2 also appears as one of several characteristic fatty acids present in eggs across all 3 development stages and was strongly retained during maturation, which may reflect its proposed role in cell membrane integrity (Le Grand et al. 2011).

\subsection{Comparative lipid distribution in $\mathbf{N}$. heros}

For the northern Neptune whelk, differences in lipid composition across size classes reflect a range of activities including varied food consumption as juve- niles transition to predatory behavior and adults that translocate lipids during reproduction. Storage lipids are particularly important to large, sexually mature whelks, which experience non-feeding or reduced feeding periods throughout winter and during copulation/spawning in spring (Pearce \& Thorson 1967, Power \& Keegan 2001). In N. heros, the reduced concentrations of total sterols and fatty acids in the largest $(>10 \mathrm{~cm})$ versus smaller whelks or mature females (H17F in Table S2) may reflect reduced feeding and transfer of lipid material to eggs through reproductive activities. $N$. heros may follow a similar strategy as the gastropod Arion empiricorum, in which foot muscle showed a decrease in lipid abundance coincident with an increase in genitalia lipids (Catalan et al. 1977). Although these field collections do not allow a direct experimental linkage to be established, it does suggest adult females retain significant lipid reserves in muscle apart from gonadal tissues.

On the Chukchi shelf, $N$. heros is dependent on primary production and intermediate consumers for food resources, and the suite of lipid markers in muscle tissues suggests it relies on both over time. We hypothesized that whelk lipid composition would reflect a changing diet with maturity, and both fatty acid and sterol distributions reflected a diverse set of dietary and modified lipids, representing direct ingestion (algal sterols and algal PUFAs), predation (C22 NMID fatty acids) and metabolic modification $\left(\Delta^{5,7}\right.$-sterols). This dietary resilience appears to occur early during their maturation, with animals of intermediate size showing similar lipid distributions and patterns in muscle tissues as the largest adults. The lipids present in likely food sources and compoundspecific carbon isotope values suggest that $N$. heros rely on modification of algal-derived sterols to produce the diagnostic suite of $\Delta^{5,7}$-sterols characteristic of gastropods. The most abundant $\Delta^{5,7}$-sterol $\left(\mathrm{C}_{27}{ }^{5,7}\right)$ may also have contributions from the dehydrogenation of cholesterol, which isotope values suggest is largely produced de novo. The lipids present in eggs not only reflect the initial transfer of largely algalderived material by adults during biosynthesis, but also selective conservation of some lipids during maturation. This region is particularly sensitive to climate change, with recent observations of decreasing ice and its earlier retreat having the potential to alter the balance of water column versus ice-derived algal production (Grebmeier et al. 2018). A shift in algal sources and its seasonal timing may decrease benthic biomass as the flux of ice-algal production to the benthos declines and a higher proportion of the 
annual primary production is recycled in the water column. Tracing lipid sources and isotopic signatures in benthic consumers such as $N$. heros provides important measures to follow trophic status and metabolic processes among benthic consumers and the dynamics of their food resources in this changing environment.

Acknowledgements. This study was funded by the US Department of the Interior, Bureau of Ocean Energy Management (BOEM), Alaska Outer Continental Shelf Region, under BOEM Cooperative Agreement No. M11AC00007 as part of the Chukchi Sea Offshore Monitoring in Drilling Area (COMIDA) and the Chemical Oceanography program of the National Science Foundation (OCE 1636045) to H.R.H. John Trefry is thanked for organic carbon values and Brenda Konar and students for trawling expertise for animal collections. Thoughtful comments by 3 reviewers substantially improved the final manuscript.

\section{LITERATURE CITED}

Ackman RG, Hooper S (1973) Non-methylene-interrupted fatty acids in lipids of shallow-water marine invertebrates: a comparison of two mollusks (Littorina littorea and Lunatia triseriata) with the sand shrimp (Crangon septemspinosus). Comp Biochem Physiol B 46:153-165

Barrett SM, Volkman JK, Dunstan GA, LeRoi JM (1995) Sterols of 14 species of marine diatoms (Bacillariophyta). J Phycol 31:360-369

Belicka LL, Macdonald RW, Yunker MB, Harvey HR (2004) The role of depositional regime on carbon transport and preservation in Arctic Ocean sediments. Mar Chem 86: 65-88

Bluhm BA, Iken K, Mincks Hardy S, Sirenko BI, Holladay BA (2009) Community structure of epibenthic megafauna in the Chukchi Sea. Aquat Biol 7:269-293

*Bazão S, Morais S, Boaventura D, Re P, Narciso L, Hawkins SJ (2003) Spatial and temporal variation of the fatty acid composition of Patella spp. (Gastropoda: Prosobranchia) soft bodies and gonads. Comp Biochem Physiol B 136: 425-441

*Budge SM, Springer AM, Iverson SJ, Sheffield G (2007) Fatty acid biomarkers reveal niche separation in an Arctic benthic food web. Mar Ecol Prog Ser 336:305-309

Catalan R, Castillon M, Rallo A (1977) Lipid metabolism during development of the mollusc Arion empiricorum. Distribution of lipids in midgut gland, genitalia and foot muscle. Comp Biochem Physiol B 57:73-79

* Dunstan GA, Volkman JK, Barrett SM, Leroi JM, Jeffrey S (1993) Essential polyunsaturated fatty acids from 14 species of diatom (Bacillariophyceae). Phytochemistry 35: 155-161

* Dunstan GA, Baillie HJ, Barrett SM, Volkman JK (1996) Effect of diet on the lipid composition of wild and cultured abalone. Aquaculture 140:115-127

* Dunton KH, Grebmeier JM, Trefry JH (2014) The benthic ecosystem of the northeastern Chukchi Sea: an overview of its unique biogeochemical and biological characteristics. Deep Sea Res II 102:1-8

Fahl K, Nöthig EM (2007) Lithogenic and biogenic particle fluxes on the Lomonosov Ridge (central Arctic Ocean) and their relevance for sediment accumulation: vertical vs. lateral transport. Deep Sea Res I 54:1256-1272

*Feder HM, Naidu AS, Jewett SC, Hameedi JM, Johnson WR, Whitledge TE (1994) The northeastern Chukchi Sea: benthos-environmental interactions. Mar Ecol Prog Ser 111:171-190

*Feder HM, Jewett SC, Blanchard A (2005) Southeastern Chukchi Sea (Alaska) epibenthos. Polar Biol 28:402-421

Feder HM, Iken K, Blanchard AL, Jewett SC, Schonberg S (2011) Benthic food web structure in the southeastern Chukchi Sea: an assessment using $\delta^{13} \mathrm{C}$ and $\delta^{15} \mathrm{~N}$ analyses. Polar Biol 34:521-532

Fujinaga K, Nakao S (1996) Population structure and mortality of the Neptune whelk Neptunea arthritica in Usu Bay, southern Hokkaido. Fish Sci 62:184-188

Fujinaga K, Nakao S (1999) A decline in RPS index of Neptunea arthritica in Usu Cove. Aquacult Sci 47:457-458

*Gergs R, Steinberger N, Beck B, Basen T, Yohannes E, Schulz R, Martin-Creuzburg D (2015) Compound-specific $\delta^{13} \mathrm{C}$ analyses reveal sterol metabolic constraints in an aquatic invertebrate. Rapid Commun Mass Spectrom 29:1789-1794

* Gladu PK, Patterson GW, Wikfors GH, Chitwood DJ, Lusby W (1991) Sterols of some diatoms. Phytochemistry 30: 2301-2303

Goad L (1978) The sterols of marine invertebrates: composition, biosynthesis and metabolites. In: Scheuer PJ (ed) Marine natural products. Chemical and biological perspectives, Vol 2. Academic Press, New York, NY, p 75-172

*Gordon DT, Collins N (1982) Anatomical distribution of sterols in oysters (Crassostrea gigas). Lipids 17:811-817

* Grebmeier JM (2012) Shifting patterns of life in the Pacific Arctic and sub-Arctic seas. Annu Rev Mar Sci 4:63-78

*Grebmeier JM, Feder HM, McRoy CP (1989) Pelagicbenthic coupling on the shelf of the northern Bering and Chukchi Seas. II. Benthic community structure. Mar Ecol Prog Ser 51:253-268

Grebmeier JM, Frey KE, Cooper LW, Kedra M (2018) Trends in benthic macrofaunal populations, seasonal sea ice persistence, and bottom water temperatures in the Bering Strait region. Oceanography (Wash DC) 31:136-151

*Harvey HR, Macko SA (1997) Catalysts or contributors? Tracking bacterial mediation of early diagenesis in the marine water column. Org Geochem 26:531-544

* Harvey HR, Bradshaw SA, O'Hara SC, Eglinton G, Corner ED (1988) Lipid composition of the marine dinoflagellate Scrippsiella trochoidea. Phytochemistry 27:1723-1729

* Harvey HR, Taylor KA, Pie HV, Mitchelmore CL (2014) Polycyclic aromatic and aliphatic hydrocarbons in Chukchi Sea biota and sediments and their toxicological response in the Arctic cod, Boreogadus saida. Deep Sea Res II 102:32-55

* Highsmith RC, Coyle KO (1990) High productivity of northern Bering Sea benthic amphipods. Nature 344:862-864

* Hummel H (1985) Food intake of Macoma balthica (Mollusca) in relation to seasonal changes in its potential food on a tidal flat in the Dutch Wadden Sea. Neth J Sea Res 19:52-76

Iken K, Bluhm B, Dunton K (2010) Benthic food-web structure under differing water mass properties in the southern Chukchi Sea. Deep Sea Res II 57:71-85

Isay S, Busarova N (1984) Study on fatty acid composition of marine organisms - I. Unsaturated fatty acids of Japan Sea invertebrates. Comp Biochem Physiol B 77:803-810 Jeffreys RM, Wolff GA, Murty SJ (2009) The trophic ecology 
of key megafaunal species at the Pakistan Margin: evidence from stable isotopes and lipid biomarkers. Deep Sea Res I 56:1816-1833

Johnson WR, Royer TC, Luick JL (1988) On the seasonal variability of the Alaska Coastal Current. J Geophys Res Oceans 93:12423-12437

Kaneda T (1991) Iso- and anteiso-fatty acids in bacteria: biosynthesis, function, and taxonomic significance. Microbiol Rev 55:288-302

Khan AS, Goad LJ (1983) The sterol constituents and $\Delta^{5,7}$-sterol content of some bivalve molluscs. Comp Biochem Physiol B 76:569-573

Kharlamenko VI, Kiyashko SI, Imbs AB, Vyshkvartzev DI (2001) Identification of food sources of invertebrates from the seagrass Zostera marina community using carbon and sulfur stable isotope ratio and fatty acid analyses. Mar Ecol Prog Ser 220:103-117

*Klingensmith JS (1982) Distribution of methylene and nonmethylene-interrupted dienoic fatty acids in polar lipids and triacylglycerols of selected tissues of the hardshell clam (Mercenaria mercenaria). Lipids 17:976-981

Kluytmans J, Boot J, Oudejans R, Zandee D (1985) Fatty acid synthesis in relation to gametogenesis in the mussel Mytilus edulis L. Comp Biochem Physiol B 81: 959-963

Kraffe E, Soudant P, Marty Y (2004) Fatty acids of serine, ethanolamine, and choline plasmalogens in some marine bivalves. Lipids 39:59-66

* Lavaud R, Artigaud S, Le Grand F, Donval A and others (2018) New insights into the seasonal feeding ecology of Pecten maximus using pigments, fatty acids and sterols analyses. Mar Ecol Prog Ser 590:109-129

Le Grand F, Kraffe E, Marty Y, Donaghy L, Soudant P (2011) Membrane phospholipid composition of hemocytes in the Pacific oyster Crassostrea gigas and the Manila clam Ruditapes philippinarum. Comp Biochem Physiol A Mol Integr Physiol 159:383-391

Kegeżyńska J, Kędra M, Walkusz W (2014) Identifying trophic relationships within the high arctic benthic community: How much can fatty acids tell? Mar Biol 161: 821-836

Lin P, Pickart RS, McRaven LT, Arrigo KR and others (2019) Water mass evolution and circulation of the northeastern Chukchi Sea in summer: implications for nutrient distributions. J Geophys Res Oceans 124:4416-4432

MacIntosh R, Somerton D (1981) Large marine gastropods of the eastern Bering Sea. In: Hood DW, Calder JA (eds) The eastern Bering Sea shelf: oceanography and resources, Vol 2. University of Washington Press, Seattle, WA, p 1215-1228

Mai K, Mercer JP, Donlon J (1996) Comparative studies on the nutrition of two species of abalone, Haliotis tuberculata L. and Haliotis discus hannai Ino. V. The role of polyunsaturated fatty acids of macroalgae in abalone nutrition. Aquaculture 139:77-89

Martínez-Pita I, García F, Pita ML (2005) Fatty acid composition and utilization in developing eggs of some marine nudibranchs (Mollusca: Gastropoda: Opistobranchia) from southwest Spain. J Shellfish Res 24:1209-1216

* McConnaughey T, McRoy CP (1979) Food-web structure and the fractionation of carbon isotopes in the Bering Sea. Mar Biol 53:257-262

McTigue ND, Dunton KH (2014) Trophodynamics and organic matter assimilation pathways in the northeast Chukchi Sea, Alaska. Deep Sea Res II 102:84-96
Morais S, Boaventura D, Ré P, Hawkins SJ (2003) Gonad development and fatty acid composition of Patella depressa Pennant (Gastropoda: Prosobranchia) populations with different patterns of spatial distribution, in exposed and sheltered sites. J Exp Mar Biol Ecol 294: $61-80$

Morton B (1990) The physiology and feeding behaviour of two marine scavenging gastropods in Hong Kong: the subtidal Babylonia lutosa (Lamarck) and the intertidal Nassarius festivus (Powys). J Molluscan Stud 56:275-288

Müller-Lupp T, Bauch H (2005) Linkage of Arctic atmospheric circulation and Siberian shelf hydrography: a proxy validation using $\delta^{18} \mathrm{O}$ records of bivalve shells. Global Planet Change 48:175-186

Nichols PD, Guckert JB, White DC (1986) Determination of monounsaturated fatty acid double-bond position and geometry for microbial monocultures and complex consortia by capillary GC-MS of their dimethyl disulphide adducts. J Microbiol Methods 5:49-55

Nichols PD, Palmisano AC, Rayner MS, Smith GA, White DC (1990) Occurrence of novel $C_{30}$ sterols in Antarctic sea-ice diatom communities during a spring bloom. Org Geochem 15:503-508

Nichols PD, Virtue P, Mooney BD, Elliott NG, Yearsley GK (1998) Seafood the good food. The oil (fat) content and composition of Australian commercial fishes, shellfishes and crustaceans. CSIRO Division of Marine Research, Fisheries Research and Development Corporation, Deakin

* North CA, Lovvorn JR, Kolts JM, Brooks ML, Cooper LW, Grebmeier JM (2014) Deposit-feeder diets in the Bering Sea: potential effects of climatic loss of sea ice-related microalgal blooms. Ecol Appl 24:1525-1542

* Olsen BR, Grahl-Nielsen O, Schander C (2009) Population study of Astarte sulcata, da Costa, 1778, (Mollusca, Bivalvia) from two Norwegian fjords based on the fatty acid composition of the adductor muscle. Biochem Syst Ecol 37:662-669

* Pearce JB, Thorson G (1967) The feeding and reproductive biology of the red whelk, Neptunea antiqua (L.) (Gastropoda, Prosobranchia). Ophelia 4:277-314

Power A, Keegan B (2001) Seasonal patterns in the reproductive activity of the red whelk, Neptunea antiqua (Mollusca: Prosobranchia) in the Irish Sea. J Mar Biol Assoc UK 81:243-250

* Ravelo AM, Konar B, Trefry JH, Grebmeier JM (2014) Epibenthic community variability in the northeastern Chukchi Sea. Deep Sea Res II 102:119-131

Saleuddin A (1965) The mode of life and functional anatomy of Astarte spp. (Eulamellibranchia). J Molluscan Stud 36: 229-257

Shimek R (1984) The diets of Alaskan Neptunea. Veliger 26: 274-281

Tamelander T, Renaud PE, Hop H, Carroll ML, Ambrose WG Jr, Hobson KA (2006) Trophic relationships and pelagic-benthic coupling during summer in the Barents Sea Marginal Ice Zone, revealed by stable carbon and nitrogen isotope measurements. Mar Ecol Prog Ser 310: 33-46

Taylor JD (1978) The diet of Buccinum undatum and Neptunea antiqua (Gastropoda: Buccinidae). J Conchol 29: 309-318

Teshima S, Patterson GW (1981) $\Delta^{5,7}$-sterols of the oyster, Crassostrea virginica. Comp Biochem Physiol B 68: 177-181 
Viso AC, Marty JC (1993) Fatty acids from 28 marine microalgae. Phytochemistry 34:1521-1533

Volkman JK (1986) A review of sterol markers for marine and terrigenous organic matter. Org Geochem 9:83-99

Volkman J, Jeffrey S, Nichols P, Rogers G, Garland C (1989) Fatty acid and lipid composition of 10 species of microalgae used in mariculture. J Exp Mar Biol Ecol 128: $219-240$

Vonk JE, van Dongen BE, Gustafsson Ö (2008) Lipid biomarker investigation of the origin and diagenetic state of sub-arctic terrestrial organic matter presently exported into the northern Bothnian Bay. Mar Chem 112:1-10

Voogt PA (1983) Lipids: their distribution and metabolism. In: Hochachka PW (ed) The Mollusca, Vol 1: Metabolic

Editorial responsibility: James McClintock,

Birmingham, Alabama, USA

Reviewed by: $P$. Virtue and 2 anonymous referees biochemistry and molecular biomechanics. Academic Press, New York, NY, p 329-370

*Weingartner $\mathrm{T}$, Aagaard $\mathrm{K}$, Woodgate $\mathrm{R}$, Danielson $\mathrm{S}$, Sasaki Y, Cavalieri D (2005) Circulation on the north central Chukchi Sea shelf. Deep Sea Res II 52: 3150-3174

K Zhukova NV (1991) The pathway of the biosynthesis of nonmethylene-interrupted dienoic fatty acids in molluscs. Comp Biochem Physiol B 100:801-804

Zimmerman CF, Keefe CW, Bashe J (1997) Determination of carbon and nitrogen in sediments and particulates of estuarine/coastal waters using elemental analysis: method 440.0. US Environmental Protection Agency, Cincinnati, $\mathrm{OH}$

Submitted: January 5, 2021

Accepted: June 21, 2021

Proofs received from author(s): August 16, 2021 